Article

\title{
Experimental Investigations and Operational Performance Analysis on Compressed Natural Gas Home Refueling System (CNG-HRS)
}

\author{
Szymon Kuczyński ${ }^{1, *(\mathbb{C})}$, Krystian Liszka ${ }^{2}$, Mariusz Łaciak $^{1}{ }^{1}$, Andrzej Olijnyk $^{1}$ and \\ Adam Szurlej $^{1}$ \\ 1 Drilling, Oil and Gas Faculty, AGH University of Science and Technology, 30-059 Krakow, Poland; \\ laciak@agh.edu.pl (M.Ł.); aoliinyk@agh.edu.pl (A.O.); szua@agh.edu.pl (A.S.) \\ 2 Independent Expert, 32-020 Wieliczka, Poland; krystian.liszka@neostrada.pl \\ * Correspondence: szymon.kuczynski@agh.edu.pl; Tel.: +48-12-617-22-47
}

Received: 18 October 2019; Accepted: 25 November 2019; Published: 27 November 2019

\begin{abstract}
Compressed natural gas can be globally used as fuel for combustion engines to reduce $\mathrm{CO}_{2}$ emission without negative impact on economy. Lack of refueling infrastructure is one of reason why NGVs shares only $\sim 1.6 \%$ in total vehicle fleet worldwide. Operational tests of CNG home fast refueling station were performed to investigate: (i) natural gas demand, $\mathrm{m}^{3} / \mathrm{h}$; (ii) energy consumption, $\mathrm{kW} / \mathrm{h}$; and (iii) total cost of one refueling. Two scenarios for operational tests were developed to monitor and collect data. Safety tests for leakage, fill pressure change, interrupted power and gas supply, temperature, and unexpected failures were performed. This article present results of operational and safety tests of compressed natural gas home, fast refueling station (CNG-HRS) based on one stage hydraulic compressor. The average duration of HRS full operating cycle was $7 \mathrm{~h}$ and $32 \mathrm{~min}$ (buffering and refueling mode). The average electric energy and natural gas consumption for one full cycle was $5.52 \mathrm{kWh}$ and $7.5 \mathrm{~m}^{3}$, respectively. Safety tests results for leakage, fill pressure change, interrupted power and gas supply, temperature and unexpected failures demonstrated valid operation of HRS which positively affects the general safety level. To compare HRS with large scale CNG refueling infrastructure the costs of $1 \mathrm{Nm}^{3} \mathrm{CNG}$ was estimated for both solutions. Results shows that home refueling appliance might be become a solution for filling the gap in CNG refueling infrastructure.
\end{abstract}

Keywords: compressed natural gas (CNG); refueling system; alternative fuels; natural gas vehicle (NGV); fueling infrastructure

\section{Introduction}

Hydrocarbon-based products like gasoline or diesel account for 95\% of all energy used in vehicles around the world. Increasing number of vehicles increases the level of air pollution. In large cities, the share of transport in air pollution accounts for $60-80 \%$ of all toxic atmospheric emissions despite modern exhaust gas purification technologies. It is difficult to achieve further significant reductions from gasoline and diesel engines. Replacing gasoline and diesel with alternative fuels, especially gaseous fuels, can play a significant role in $\mathrm{CO}_{2}$ emission reduction by $10-15 \%$ [1].

Natural gas has several significant advantages in relation to hydrocarbon fuels. Natural gas is currently the cleanest available alternative (combustible) fuel in transport [2,3]. There are large identified resources while there is lack of fueling infrastructure. Natural gas is safe, lighter than air, and does not remain on the surface like liquid fuels. Natural gas is also economical to use, because it is about $40 \%$ less expensive than gasoline, despite slightly higher CNG consumption, the cost of fuel is still cheaper. Natural gas is a bridge to hydrogen transportation fuel $[4,5]$. 
According to The Gas Vehicle Statistics Report from July 2019, there are currently around 27.7 million natural gas vehicles in the world and 32.5 thousand natural gas fueling stations [6]. In Europe, over 2 million vehicles and over 5 thousand stations (fuels include CNG, LNG, and RNG). Since 2000, the number of global NGVs has increased by over 26 million but the number of refueling stations is still insufficient [7,8]. Currently, over 3700 CNG and 232 LNG refueling stations operate in Europe [9].

In line with the goals presented in the 2011 White Paper on Transport-i.e., a 20\% reduction in the GHG emissions by 2030 relative to 2008 levels and a $60 \%$ reduction by 2050 relative to 1990 levels-strong efforts are required to drastically reduce the oil dependency and the greenhouse gas (GHG) emissions in the transport sector [10].

The experience of several countries indicates the need to establish a uniform European system for the use of compressed and liquefied natural gas (CNG and LNG) in trucks and buses [11,12]. Such a system can significantly help solve the problems of air and environmental pollution in Europe. The use of natural gas in trucks (heavy duty vehicle) and international buses will have a positive impact on the environment in Europe. Individual transport will also contribute to this improvement. 2018 Global Gas Report states that more than $90 \%$ of global gas consumption growth to 2040 will come from cities [13]. To increase number of natural gas vehicles (NGV's) development of refueling infrastructure is required. It includes large, medium, and small scale (home) refueling infrastructure [14,15]. Worldwide share of CNG stations from total amount of fuel stations in 2015 was 3.6\% [16]. In 2015, over 100 million of households were connected to natural gas grid in EU which could use small (home) scale refueling devices to fill the gap in large scale CNG refueling infrastructure. The lack of cost-effective appliances is the main barrier in the development of small scale CNG infrastructure in urban, suburban, and rural areas $[17,18]$.

The purpose of this article is to present the results of operational and safety tests of CNG home fast refueling station (HRS) developed by Hygen [19]. All tests and measurements were carried out on single prototype unit provided by the manufacturer. Results show electricity consumption and natural gas demand for various scenarios of HRS operation, i.e., different level of residual gas pressure in the refueled tank of vehicle or for different refueling duration. The paper also shows results for refueling speed of NGV by investigated HRS prototype.

To assess the overall safety level, HRS has been investigated in various operating conditions. For example in case of: (i) a rapid pressure change in a low pressure distribution network; or (ii) rapid stop of natural gas or electricity supply to the HRS. During safety tests, tightness and temperature of selected HRS elements were monitored.

Based on the obtained results, the unit cost of vehicle refueling with CNG was estimated (for Polish conditions) [20]. Results enable estimation of operational costs of the HRS in conditions of any country.

\section{Operation Principle of CNG Home Fast Refueling System}

The technology of CNG HRS is based on one stage hydraulic compressor (instead of multistage mechanical compressor technology) which provides the possibility to compress low pressure gas from residential gas grid to 200 bar for its further usage as a fuel for NGVs (Figure 1). HRS consists of three modules: main block, pump block, and electronic controlling unit (ECU). The main block includes two high pressure hydraulic cylinders $32 \mathrm{~L}$ each and four high pressure storage cylinder $22 \mathrm{~L}$ each (20.1-20.4). The main block includes two high pressure working cylinders (1), (2) with upper necks connected to low pressure gas source (natural gas distribution network). Initially, a high-pressure working cylinder (1) is filled with liquid and the cylinder is filled (2) with low pressure natural gas [21]. The pump block includes two electrical engines connected in series and a hydraulic pump which transfer the working fluid between HP working cylinders (1 and 2). During this process, the liquid level in working cylinder (2) rises. As a result, the gas pressure in cylinder 2 increases and after reaching an appropriate pressure multivalve allows to transfer gas out into the storage cylinders (20.1-20.4). At 
the same time, the level of working fluid in working cylinder (1) decreases, which causes intake of low pressure natural gas from the grid. When all fluid is pumped out from one working cylinder into another the working cycle is completed. After each working cycle the pressure of natural gas inside storage cylinders is raising up [21]. This process is repeated until the gas pressure in the storage tank reaches $\sim 200$ bar after which HRS automatically stops. This operation is called 'gas buffering mode'. This mode is one of the two operation regimes of the HRS. The second operation mode is refueling.

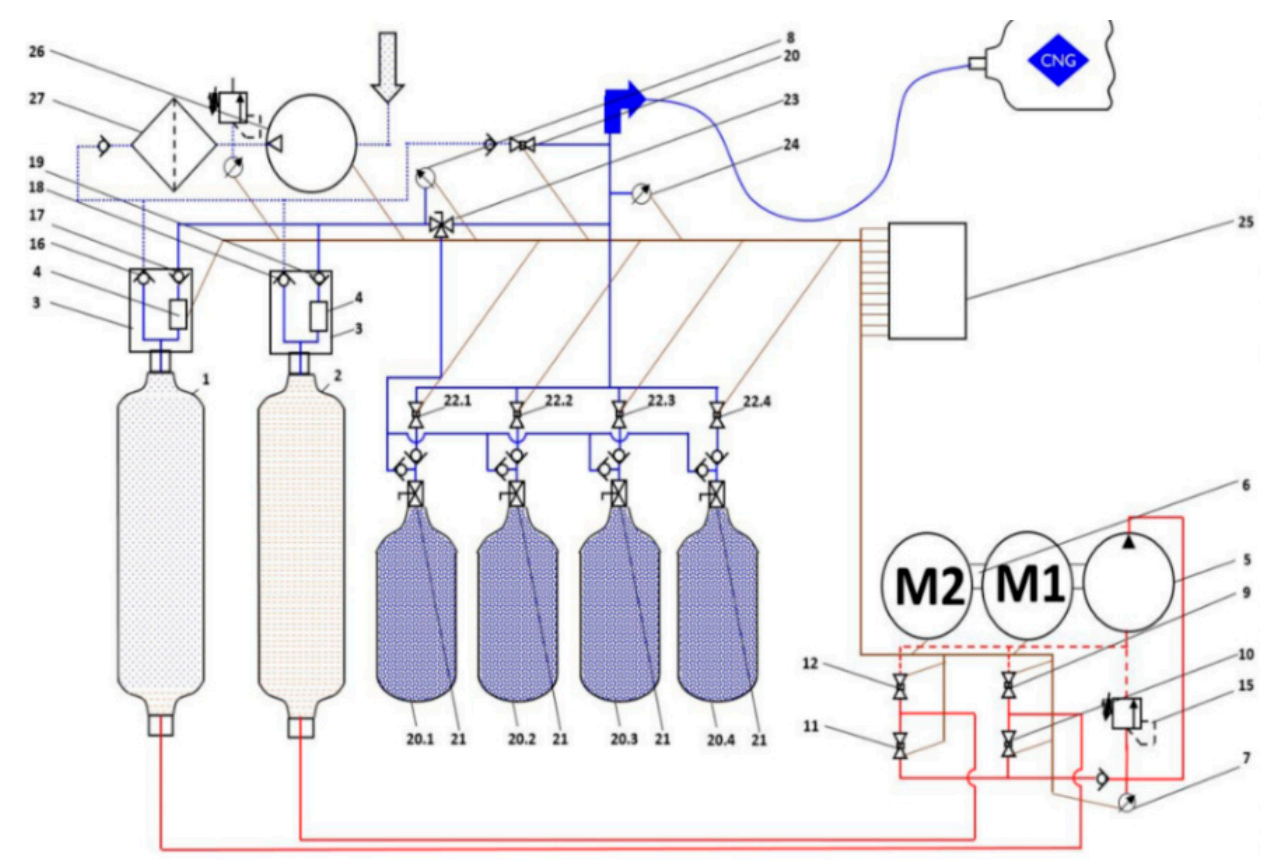

Figure 1. Technical scheme of CNG home fast refueling system [19]: 1. Compressing cylinder no. 1; 2. Compressing cylinder no. 2; 3. Multivalve; 4. Fluid level sensor; 5. Hydraulic pump; 6. Electric drive system; 7, 8, 24. Digital pressure sensor; 9, 12. Low-pressure hydraulic solenoid valve; 10, 11. High-pressure hydraulic solenoid valve; 15. Hydraulic bypass valve; 16-19. Check valve; 20.1-20.4. Storage cylinders; 21. High-pressure manual valve with built-in PRD; 22.1-22.4. High-pressure solenoid gas valve; 23. Switch valve; 25. ECU; 26. Pre-compressor; 27. Filter.

In refueling mode, the tanking hose needs to be connected to the vehicle CNG storage cylinder. Then electromagnetic valves (22.1-22.4) on storage cylinders (20.1-20.4) opens and the compressed natural gas flows out through the hose to the CNG cylinder installed in the vehicle.

The gas flows from storage cylinders as consequence of pressure difference between the storage cylinders and NGV CNG storage cylinder. Refueling is continued until the pressures in both cylinders are equal.

During the tests, HRS was combined with experimental setup. HRS was not connected to a real natural gas grid. The source of natural gas supply for HRS was a CNG tank which was a part of the experimental setup. Also, HRS was refueling experimental setup (same CNG tank) which simulated refueling of real NGV tank.

\section{Design of Experimental Setup for HRS Investigation}

Experimental setup was designed and constructed to perform operational and safety tests for a final prototype of CNG home fast refueling system (CNG HRS). The experimental setup consists of two parts: a natural gas installation, and a telemetry and automatic system part. 


\subsection{Technical Design of Natural Gas Installation}

The closed cycle of natural gas installation was designed for the experimental setup due to: (i) expecting large volumes of natural gas needed for the tests; (ii) speeding up the tests; and (iii) avoiding real NGV refueling and usage the fuel in road conditions [22].

The natural gas installation part consists of two CNG tanks, $60 \mathrm{dm}^{3}$ each (7). This type of tank is actually used in CNG NGV installations [23]. Each CNG tank is equipped with: a check valve (4) which prevents through backflow during fueling; electronic shut-down valve (6) which cuts off the CNG tank from the rest of the installation to prevent natural gas flow in case of leakage and/or an emergency event; manometers and pressure transmitters (5). To reduce the pressure and manage the gas flow, a valve (2) and CNG pressure reducer (9) are installed. Then follows: a temperature sensor (8), mid-pressure tank, $40 \mathrm{dm}^{3}$ (11) with nominal pressure 12.5 bar, low pressure reducer MIX-10 (12) and low-pressure tank $40 \mathrm{dm}^{3}$ with nominal pressure $12.5 \mathrm{bar}$. The installation is also equipped with a diaphragm gas meter (14). The experimental setup for the performance investigation of HRS is presented in Figure 2.

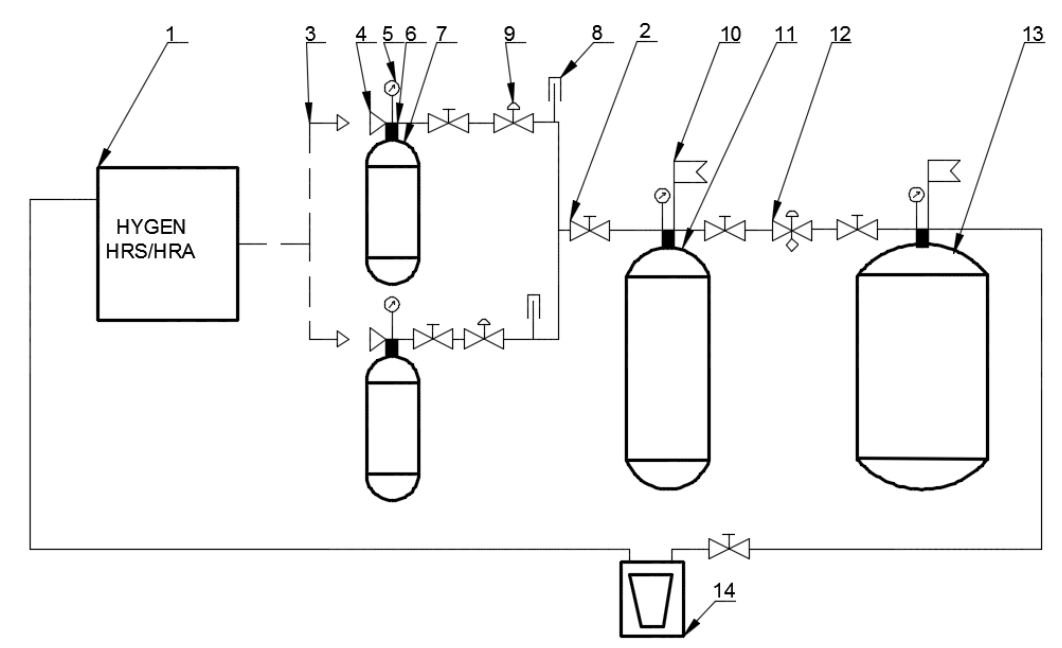

Figure 2. Experimental setup for the performance investigation of HRS (own design) 1. Home refueling unit; 2 . Valve; 3 . Refueling head; 4 . Check valve; 5 . Pressure transmitter; 6 . Electronic shut-down valve; 7. CNG tank; 8. Temperature transmitter; 9 . Pressure reducer from 200 bar to 5 bar; 10 . Discharge valve; 11. Mid-pressure tank ( 5 bar); 12. Pressure reducer from 5 bar to 0.03 bar connected with shut-down valve; 13. Low-pressure tank (0.03 bar); 14 . Gas meter.

Initially, both CNG tanks were filled with high pressure natural gas from the external source. At the beginning of the buffering mode, the natural gas pressure in the CNG tank was 120 bar. The gas pressure in CNG tank was measured and recorded with a manometer and pressure transmitter. Then, natural gas flows through the open valve to the CNG pressure reducer, where the gas pressure was lowered to 5 bar. A huge drop of pressure evokes the Joule-Thomson effect, i.e., considerable lowering gas temperature. To prevent the CNG pressure reducer against this phenomenon (freezing) it was heated with a special intrinsically safe electro-resistance heater. After CNG pressure reduction, the gas temperature was measured with a temperature transmitter installed right after the reducer. After reduction, natural gas flows to the mid-pressure tank. Due to magnitude of the pressure reduction (from 120 to 5 bar) and relatively high gas flow, the operation of CNG reducer was uneven. The mid-pressure tank was installed to mitigate the pressure oscillations after the reduction and to provide constant gas supplies to the tested HRS unit. Then, natural gas leaves the mid-pressure tank and flows through the low-pressure reducer which lowers gas pressure to 0.03 bar. After low-pressure reduction gas flow to low-pressure tank. From the low pressure tank, natural gas flows through gas meter (14) and feeds the HRS. At the end of the buffering mode the pressure in CNG tank equals to about 5-25 bar. The total gas volume from the CNG tank was buffered in HRS buffering cylinders. 
During refueling mode, the natural gas from HRS storage cylinders flows to the CNG tank of the experimental setup (Figure 3). The refueling is continued until the pressures in HRS storage cylinders and the CNG tank are equal. Such methodology enables a great number (long term) of test cycles on HRS unit without connation existing natural gas grid and to avoid real NGV refueling and usage the fuel in road conditions.

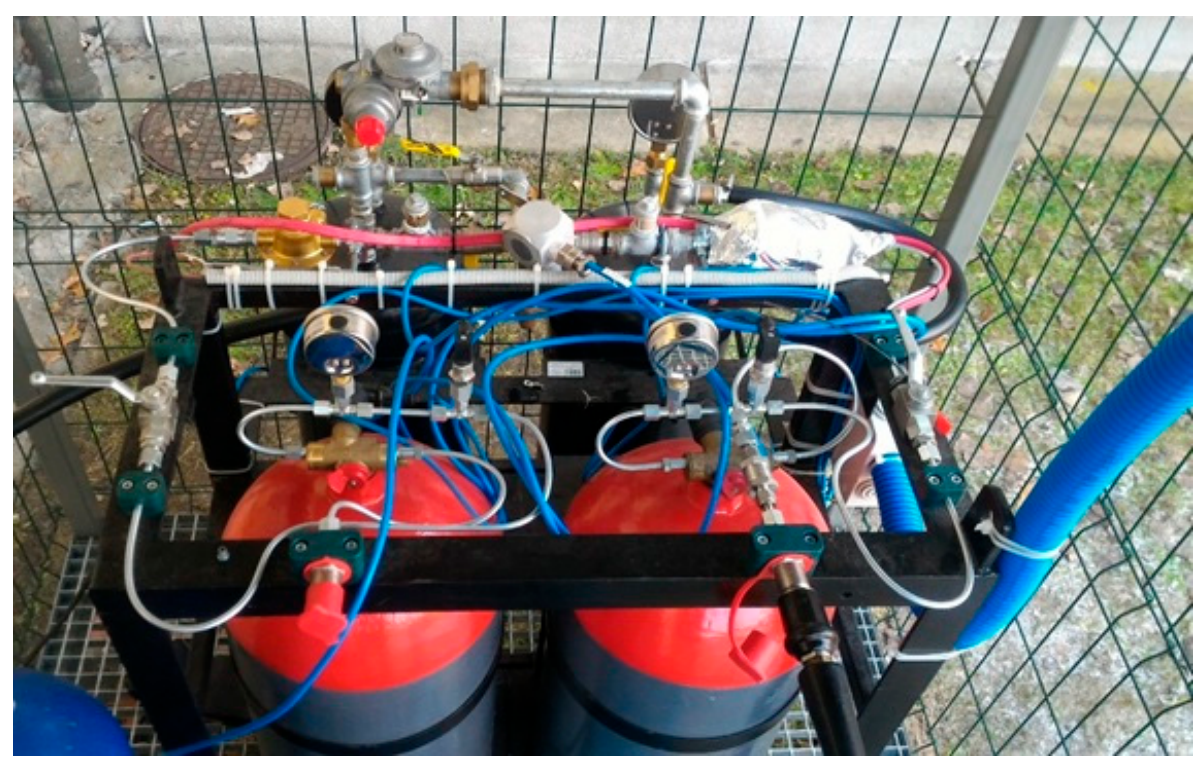

Figure 3. Experimental setup for the performance investigation of HRS (own design).

\subsection{Technical Design of Telemetry and Control System}

The designed telemetry and automatic system cooperates with six pressure and six temperature transmitters. Also, the electric energy and natural gas consumption was measured and recorded. All sensors which operated in hazardous zone were connected with the use of barriers and intrinsically safe transmitters (with ATEX certificate). All measurements were recorded both on a micro SD card and a PC with the use of a software with protocol S7. The atmosphere around HRS and experimental setup was monitored to with a Gazex system to detect explosive atmosphere. In the case of detection of explosive atmosphere, the control system should undertake appropriate action to ensure a safe stop of the compression and expansion processes. A safety switch which triggers the safe stop mode was installed in an easily accessible place. Due to the use of standard solutions in the entire telemetry and control system relays, contactors do not have an adequate safety integrity level (SIL) and this switch cannot be treated as a classic emergency shutdown system (ESD). In emergency and alarm situations, when the given thresholds of measured parameters (pressure and temperature) are exceeded or the gas concentrations are too high, the system shall perform the following actions: (i) switch off the HRS and (ii) close the electronic shut-down valve. The logical scheme of the telemetry and control system is presented on Figure 4. 


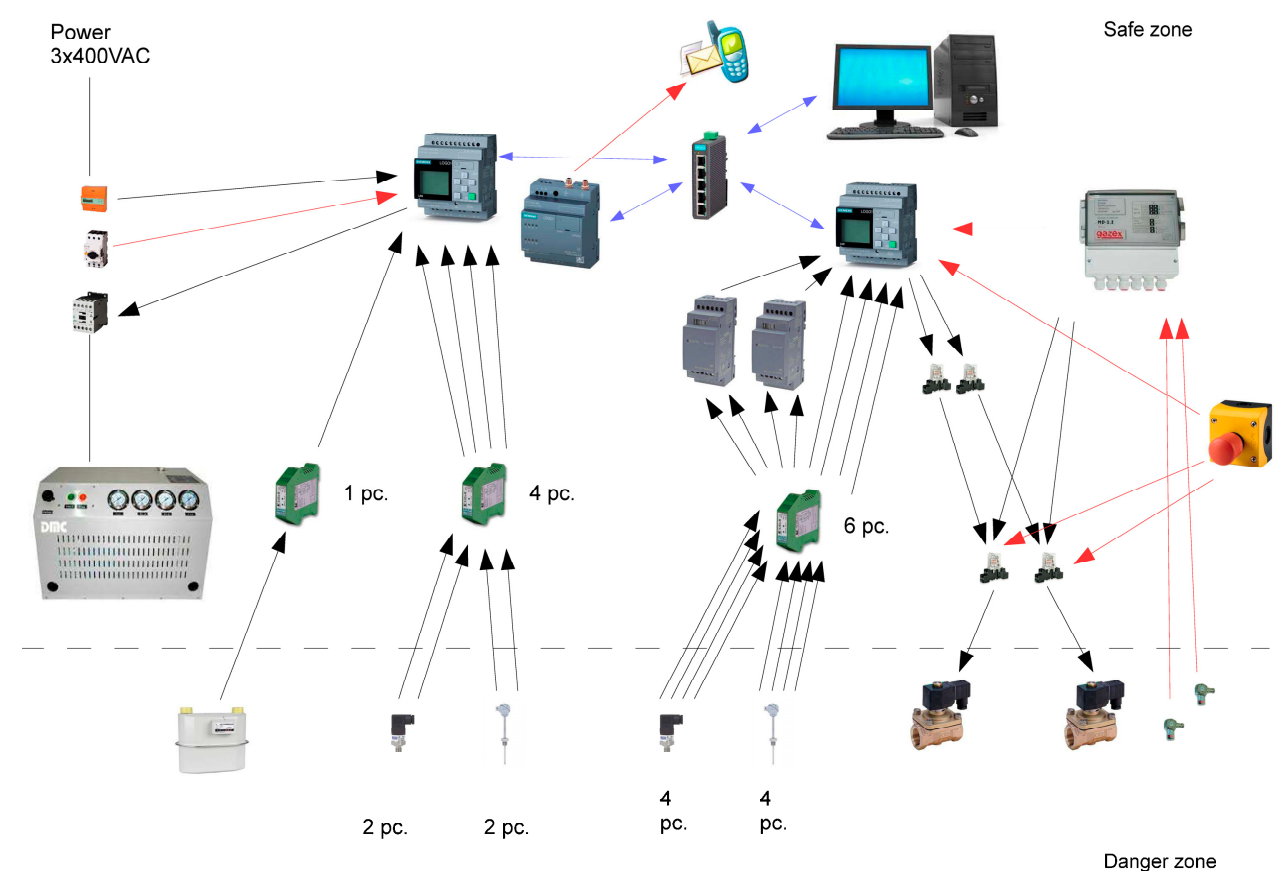

Figure 4. Logical scheme of telemetry and control system (own design).

The information about alarms in the system is additionally sent by SMS to the indicated telephone number. All elements of: measuring circuits; control circuits; gas detection system; system for recording and control-LOGO controllers, overcurrent protection, electric energy counter, and contactor were installed in a special box.

\section{Research Methodology}

The aim of the investigation was to perform operational and safety tests for a final production prototype of CNG home fast refueling system (CNG HRS).

\subsection{Performance Tests}

During the operational tests of CNG HRS, the main investigated parameters were: (i) natural gas demand, $\mathrm{m}^{3} / \mathrm{h}$; (ii) energy consumption, $\mathrm{kW} / \mathrm{h}$; and (iii) total cost of one refueling. Methodology for two scenarios for operational tests was developed to monitor, collect data, and to analyze results of selected parameters.

The first scenario assumed to perform 21 full operational cycles. One full cycle consists of one buffering mode (until the pressure in storage cylinders reach 200 bar) and one refueling mode during which gas flow until pressure in storage cylinders and NGV CNG tank are equal.

The second scenario assumed to perform 50 buffering and refueling modes which included 16 cycles with $6 \mathrm{~h}$ duration (with additional $30 \mathrm{~min}$ in standby mode), 17 cycles with $5 \mathrm{~h}$ duration (with additional $30 \mathrm{~min}$ of standby) and 17 cycles with $4 \mathrm{~h}$ duration (with additional $30 \mathrm{~min}$ of standby). During second scenario, the buffering mode was finished earlier (before reaching 20MPa in storage cylinders) but after 6,5 , and $4 \mathrm{~h}$ of operation.

\subsection{Safety Tests}

The aim of the safety tests was to analyze safety aspects of HRS prototype. Various scenarios, operational conditions, and situations were simulated and analyzed to estimate the general safety level of HRS. To determine general safety level, requirements from ANSI standard $[24,25]$ were applied. During the safety tests, the following sources of hazard were taken into consideration: 
i. Leakage. All pressure-bearing parts and components, including joints and connections, shall not leak directly to the atmosphere in excess of the limit specified below when subjected to an internal gauge pressure not less than $0.5-1$ times the maximum pressure to which they are exposed during intended use.

ii. Fill pressure changes. The HRS shall be provided with a pressure-sensing device that shuts down the HRS upon a sudden drop ore rise in fill pressure.

iii. Interrupted current supply. Independent (beyond user's control) circumstances such as power supply interruption may occur. In such situations, the tested device should safely stop operation. After the power is restored, the HRS should safely stop working. When resuming power supply, the HRS should remain in the initial (standby) mode. After enabling the appropriate operating mode, it should start operation without any problems.

iv. High temperature. High temperature of some elements of the device may cause a fire, which is a very serious threat, considering the fact that HRS operates with natural gas.

v. HRS equipment failures.

\section{Results and Discussion}

\subsection{Operational Tests}

Operational tests of CNG HRS were conducted for several weeks. As a result, it was possible to gather a large amount of data on natural gas and electrical energy consumption for further analysis.

\subsubsection{Results for Scenario 1}

During Scenario 1, HRS in combination with experimental setup, performed 21 full operating cycles, which are equivalent to 21 buffering and 21 refueling cycles. During this test, the CNG tank fulfills two functions: (i) while HRS was operating in buffering mode, the CNG tank functioned as natural gas source for HRS. Natural gas from the CNG tank flows through the high pressure reducer, mid-pressure tank, low-pressure reducer, and then to the low-pressure tank to feed the HRS with low pressure natural gas. In this mode, natural gas via hydraulic compression was transferred to HRS storage cylinders until the gas pressure reach 200 bar; (ii) while HRS was operating in refueling mode, natural gas flows from HRS storage cylinders to the CNG tank (simulated NGV tank). HRS refueling mode lasts 10-15 min. In this time, natural gas pressure in HRS storage cylinders decreased while natural gas pressure in the CNG tank raised. Figure 5 presents a natural gas pressure change in the CNG tank (which reflects two operational modes of HRS).

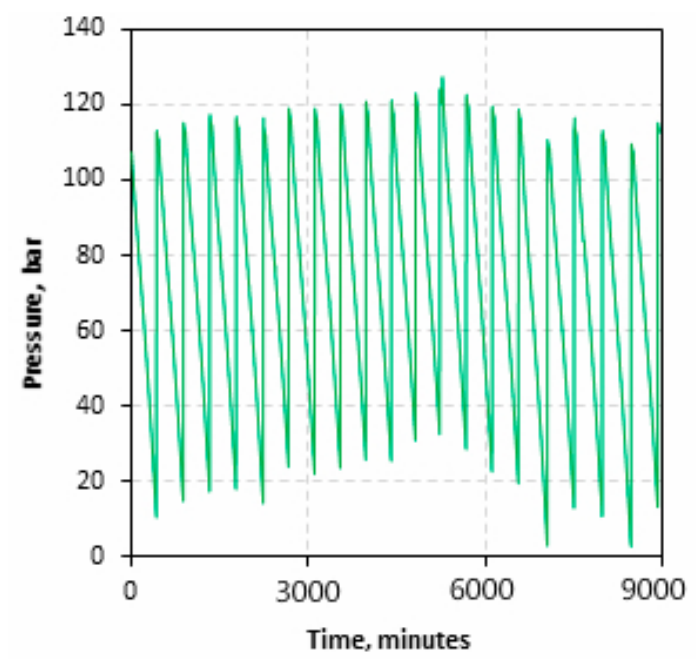

Figure 5. Pressure change in high pressure CNG tank (simulated NGV tank) in experimental setup for Scenario 1. 
Figure 5 shows the natural gas pressure change in the CNG tank for each cycle. Cycle amplitude indicates slow pressure decrease (from 110-120 bar to 5-20 bar) which corresponds to buffering mode and fast pressure increase (up to 120 bar) as a result of refueling mode. During this scenario ambient temperature was monitored (Figure 6). Cycle pressure amplitude is correlated with ambient temperature. The ambient temperature during the Scenario 1 oscillated from $+10{ }^{\circ} \mathrm{C}$ to $-4{ }^{\circ} \mathrm{C}$.

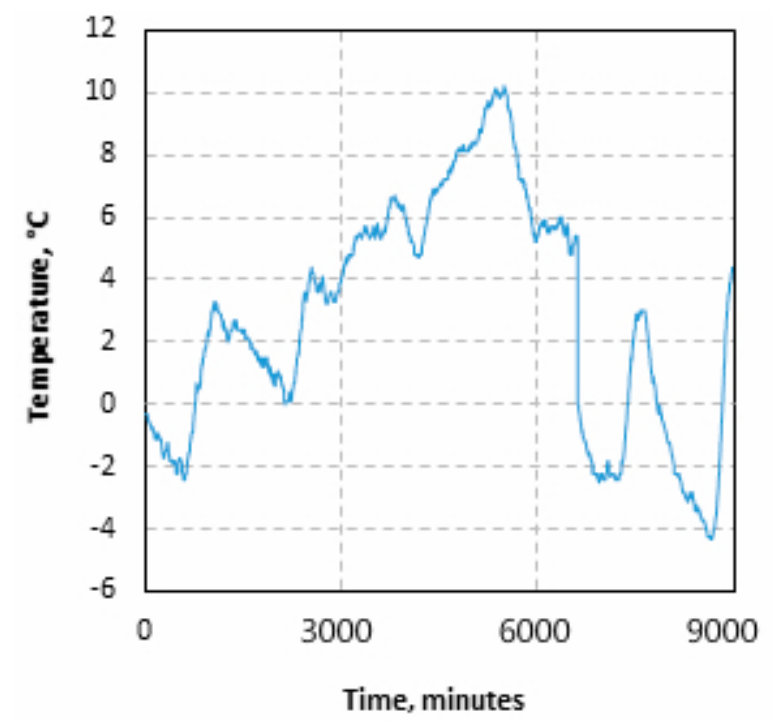

Figure 6. Ambient temperature for Scenario 1.

As a result of the operational test Scenario 1, it was demonstrated that the average duration of HRS full operating cycle was $7 \mathrm{~h}$ and $32 \mathrm{~min}$ (buffering and refueling mode).

Electric energy consumption and cycle duration for test Scenario 1 for each HRS full operating cycle is presented on Figure 7. The average electric energy consumption for one full cycle was $5.52 \mathrm{kWh}$.

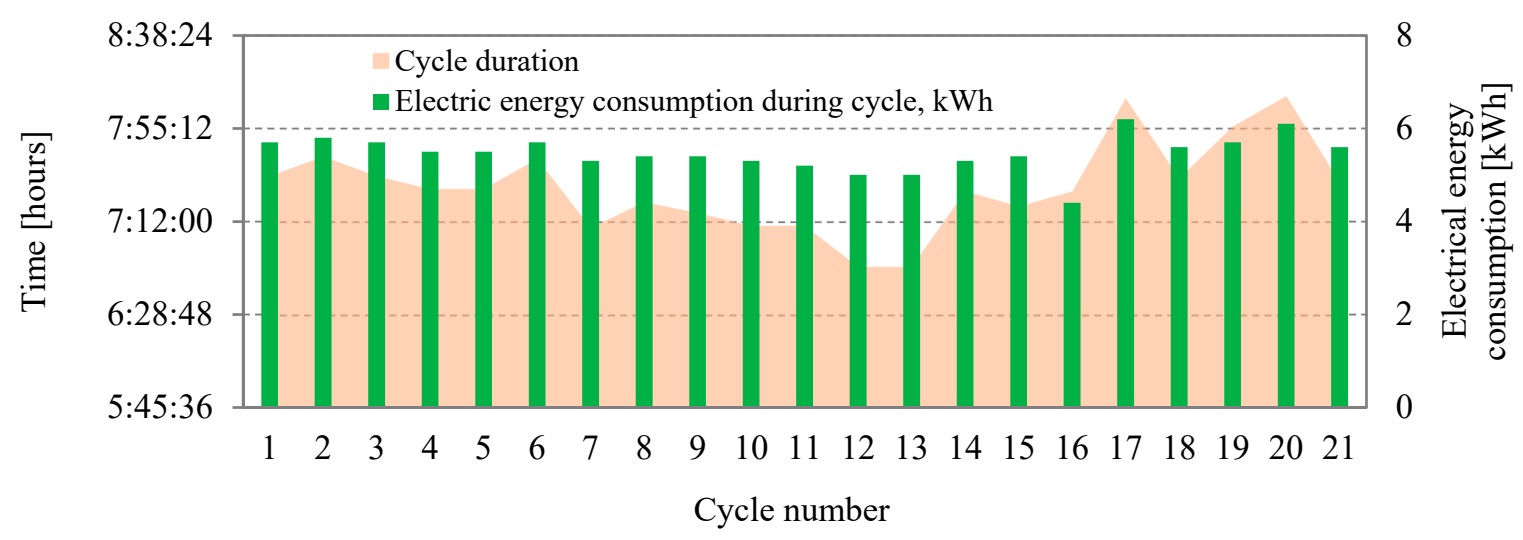

Figure 7. Electric energy consumption vs. HRS operational cycle duration for test Scenario 1.

The analysis of the obtained results reveals that the hourly electric energy consumption for a given scenario and ambient conditions was $0.74 \mathrm{~kW} / \mathrm{h}$.

Natural gas consumption and cycle duration for test Scenario 1 for each HRS full operating cycle is presented on Figure 8. The average natural gas consumption for one full cycle equaled $7.5 \mathrm{~m}^{3}$. 


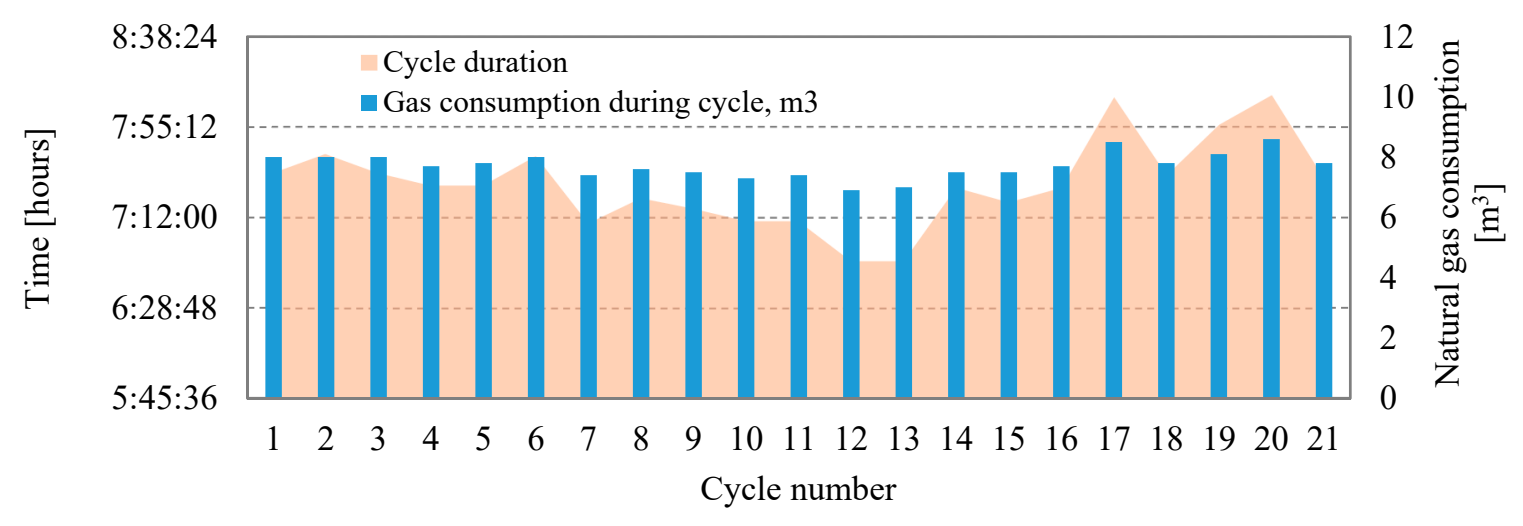

Figure 8. Natural gas consumption vs. HRS operational cycle duration for test Scenario 1.

The analysis of the obtained results reveals that the hourly natural gas consumption for a given scenario and ambient conditions was $1.00 \mathrm{~m}^{3} / \mathrm{h}$.

\subsubsection{Results for Scenario 2}

During Scenario 2, HRS in combination with experimental setup performed 50 buffering and refueling cycles where: (i) 16 cycles sustained $6 \mathrm{~h}$ (with additional $30 \mathrm{~min}$ of standby), (ii) 17 cycles sustained $5 \mathrm{~h}$ (with additional $30 \mathrm{~min}$ of standby), and (iii) 17 cycles sustained $4 \mathrm{~h}$ (with additional 30 min of standby).

The first purpose of this scenario was to simulate refueling process of the NGV's tank with different levels of filling. Differently from Scenario 1, pressure in the HRS storage cylinder did not reach 200 bar due to forced stop of buffering mode (after 4, 5, and $6 \mathrm{~h}$ of operation in buffering mode). Shorter buffering mode caused smaller pressure decrease in CNG tank. In comparison to Scenario 1, refueling mode starts with higher pressure in CNG tank. This can simulate different fill levels of the NGV's tank. HRS refueling mode lasts 10-15 min. In this time, natural gas pressure in HRS storage cylinders decreased while natural gas pressure in the CNG tank raised. Figure 9 presents a natural gas pressure change in the CNG tank (which reflects two operational modes of HRS).

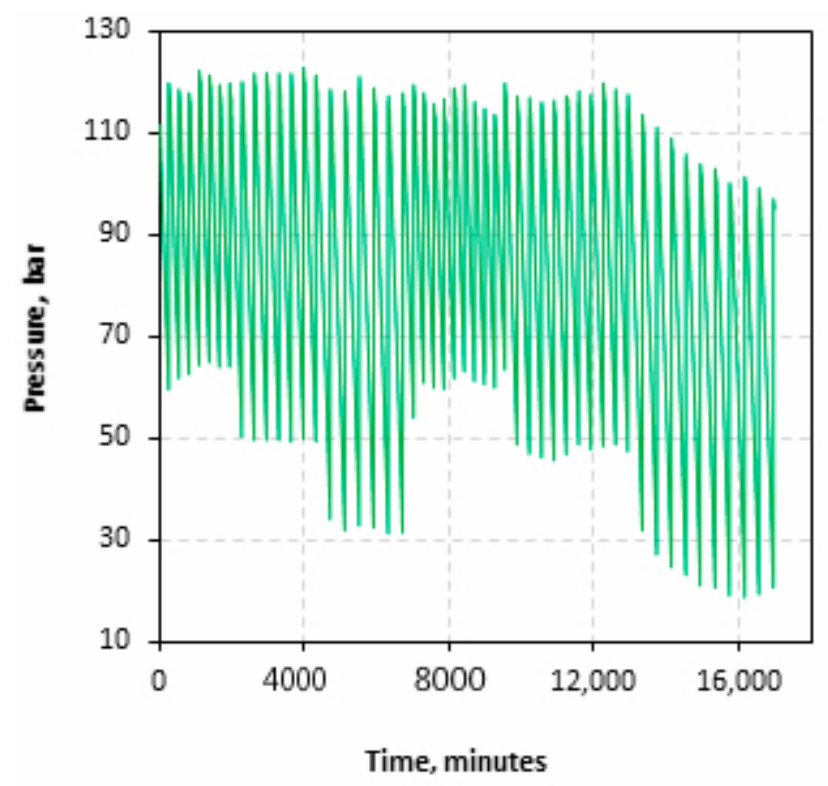

Figure 9. Plot of pressure change in high pressure tank (simulated NGV tank) in experimental setup for Scenario 2. 
The second purpose of this scenario was to simulate real life conditions during which refueling mode starts after rapidly stopped buffering mode after 4,5 , and $6 \mathrm{~h}$ of operation.

Figure 9 shows the natural gas pressure change in the CNG tank for each cycle. Cycle amplitude for buffering modes indicates slow pressure decrease: for $4 \mathrm{~h}$ cycles from 120 to $60 \mathrm{bar}$; for $5 \mathrm{~h}$ cycles from 120 to $45-50$ bar; for $6 \mathrm{~h}$ cycles from 120-100 to 30-20 bar. As a result of refueling mode pressure increase (up to 100-120 bar for all cycles). Cycle pressure amplitude is correlated with ambient temperature. The ambient temperature during the Scenario 1 oscillated from $+5^{\circ} \mathrm{C}$ to $-17^{\circ} \mathrm{C}$ (Figure 10).

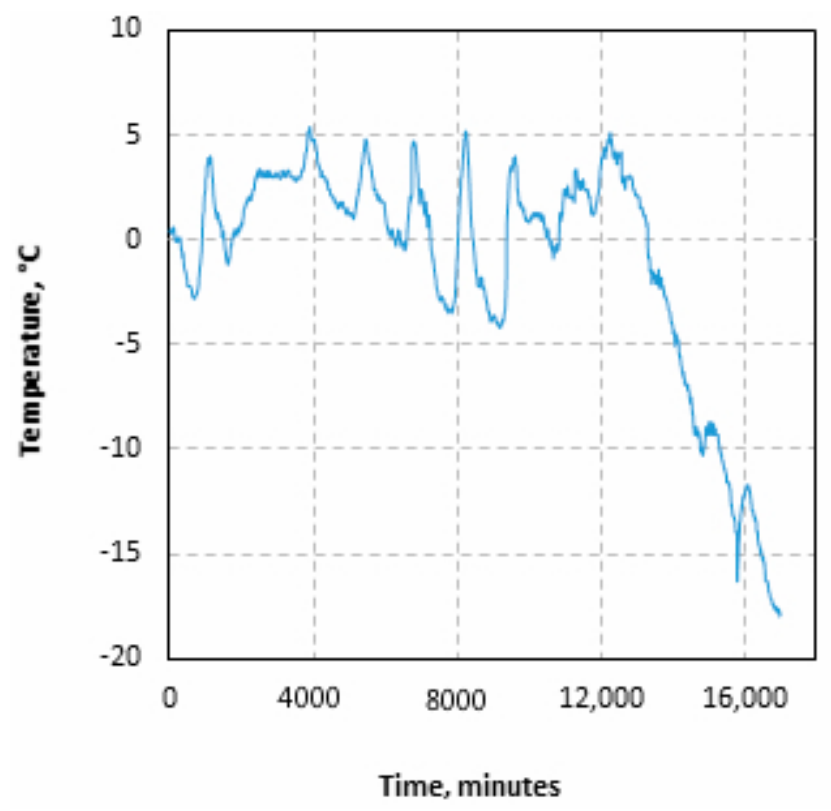

Figure 10. Plot of ambient temperature for Scenario 2.

Electric energy consumption and cycle duration for test Scenario 2 for each HRS operating cycle is presented on Figure 11. As a result of the operational test Scenario 2, it was demonstrated that in the 4-h cycle, the electric energy consumption was 3.2-3.3 kWh. For the 5- and 6-h cycles, the electric energy consumption was 4.0-4.1 kWh and 4.8-5.0 kWh, respectively.

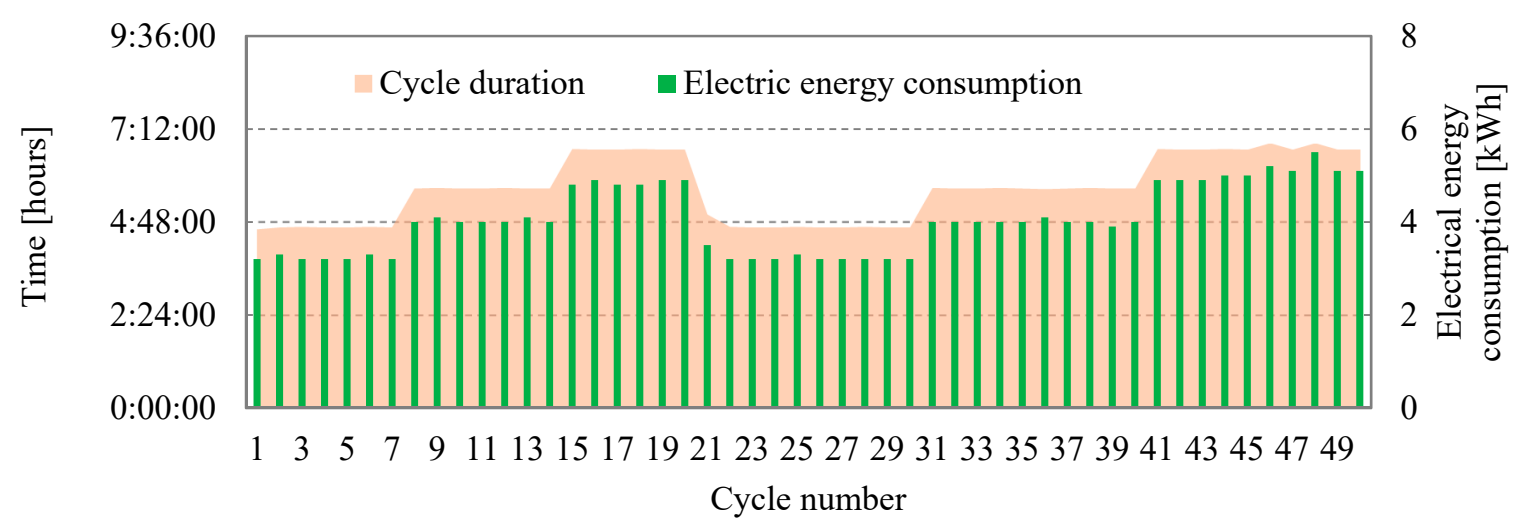

Figure 11. Electric energy consumption vs. HRS operational cycle duration for test Scenario 2.

Natural gas consumption and cycle duration for test Scenario 2 for each HRS operating cycle is presented on Figure 12. As a result of the operational test Scenario 2, it was demonstrated that in the 4 -h cycle, the natural gas consumption was $4.5-4.6 \mathrm{~m}^{3}$. For the 5- and 6-h cycle, the natural gas consumption was $5.6-5.7 \mathrm{~m}^{3}$ and $6.6-6.8 \mathrm{~m}^{3}$, respectively. 


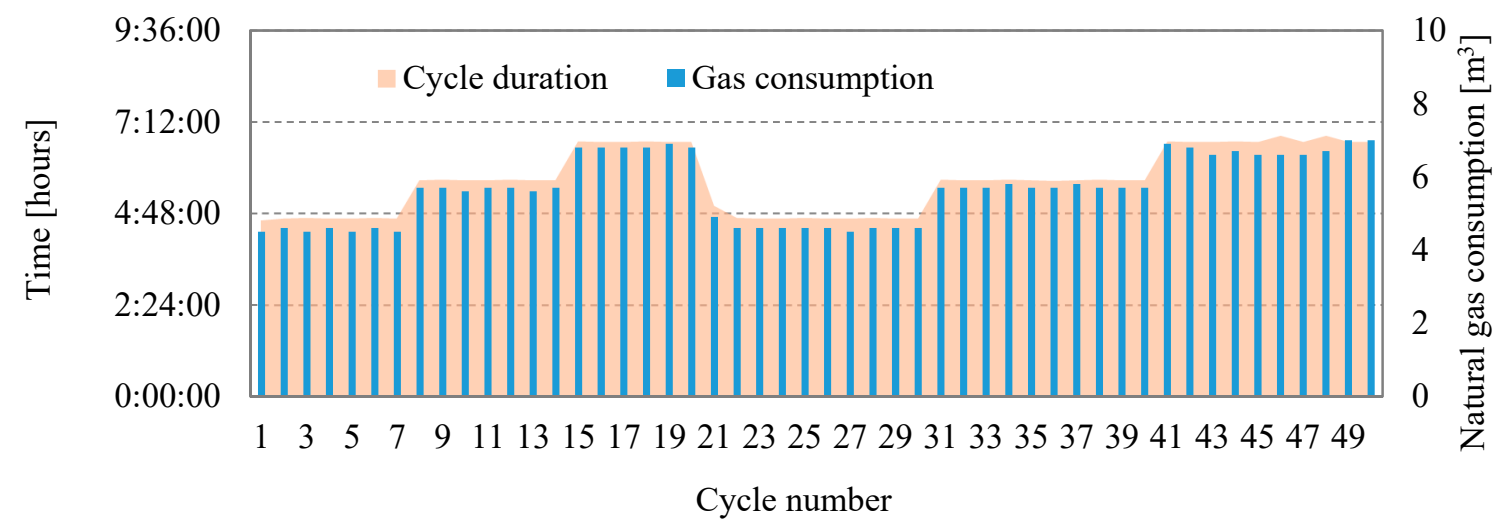

Figure 12. Natural gas consumption vs. HRS operational cycle duration for test Scenario 2.

The analysis of the obtained results reveals that the hourly energy and natural gas consumption for a given scenario and ambient conditions equal to $0.8-0.83 \mathrm{~kW} / \mathrm{h}$ and $1.1-1.15 \mathrm{~m}^{3} / \mathrm{h}$, respectively.

\subsection{Results of Safety Tests}

\subsubsection{Leakage}

Because some parts of HRS installation were connected with screw joining, special attention to the tightness of the installation was needed. The tightness of piping connections was investigated with methane detector during HRS operation. The tests revealed some leakage spots in piping connections on high pressure part of installation which were eliminated. HRS was equipped with a methane detector which was connected to ECU. In case of reaching methane concentration level at $30 \%$ of lower explosive limit (LEL), ECU stops HRS. During the tests the gas sensor did not record any signal, which proved insignificant level of leakage.

\subsubsection{Fill Pressure Changes}

HRS was equipped with gas pressure sensor installed on low pressure HRS supply piping. It was installed to protect HRS against a pressure drop in natural gas distribution network. The efficiency of the pressure sensor on supply piping was monitored. The natural gas composition did not influence the gas pressure sensor [26]. Correct operation of the pressure sensor was found, which positively affects the general safety level of the analyzed HRS.

\subsubsection{Interrupted Current Supply}

Independent (beyond user's control) circumstances may occur such as power supply interruption. In such a situation, the HRS safely stop operation and after resuming power supply, the HRS remain in the standby mode, and after enabling switching one of the two operation modes of HRS (buffering or refueling), it started to operate correctly. Described behavior positively influences the general safety level of the HRS.

\subsubsection{High Temperature}

During operation of HRS, the only element which was heated to relatively high temperatures was the pump block which includes a hydraulic pump and electric motor. The temperature of the hydraulic pump and electric motors was monitored with an infrared thermography. Measurements were performed with a thermographic camera Avio Thermo Tracer NEC H2640 (AVIO, Tokyo, Japan). Images were taken at room temperature $\left(\mathrm{ca} .20^{\circ} \mathrm{C}\right.$ ) with a distance between camera lens and the object of about $50-150 \mathrm{~cm}$. The installed hydraulic pump was equipped with six valves. Four of them were active during the tests (two hottest are presented below). The average temperature of the valves 
reached about $55^{\circ} \mathrm{C}$ and was different along their height as presented on images (Figure 13). Figure 14 shows boundaries of the rectangles surfaces for which temperature was determined (dashed line).

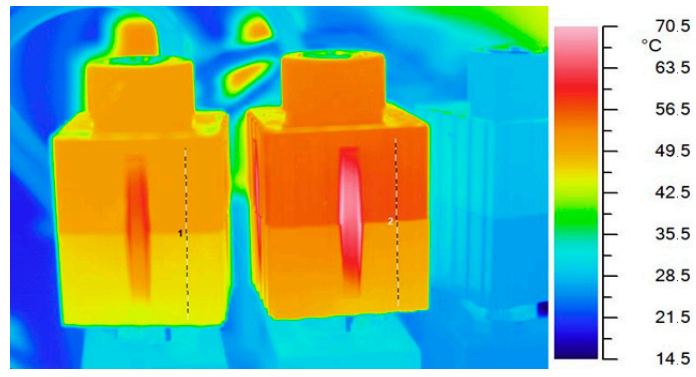

Figure 13. Thermographic image for selected valves (Sections 1 and 2).

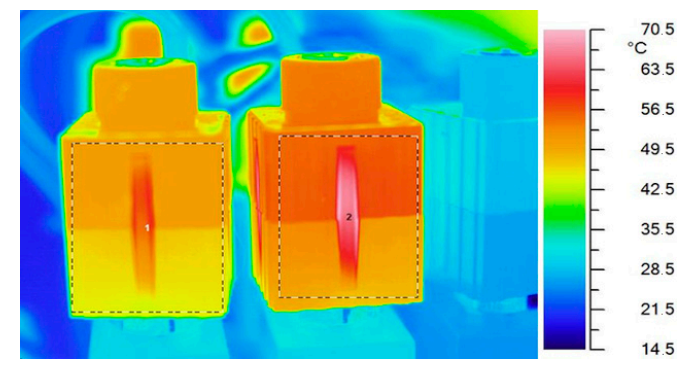

Figure 14. Surface boundaries for temperature analysis of selected valves (Sections 1 and 2).

Figure 15 shows vertical temperature profile of investigated valves. Surface temperature of analyzed elements differs by about $4.5 \mathrm{~K}$. The valve (profile 2) heats up to a higher temperature and the difference may even reach $6 \mathrm{~K}$. The vertical temperature profile is presented in Figure 15.

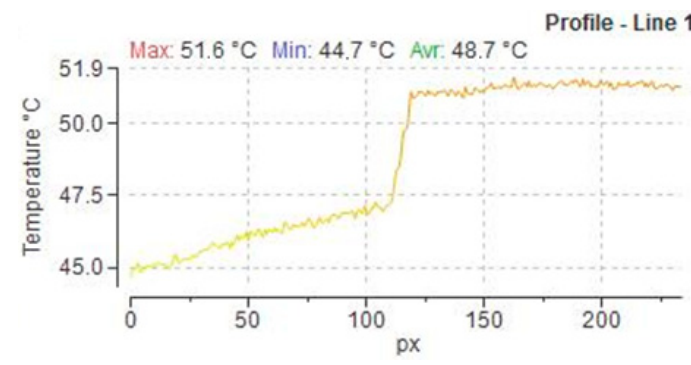

(a)

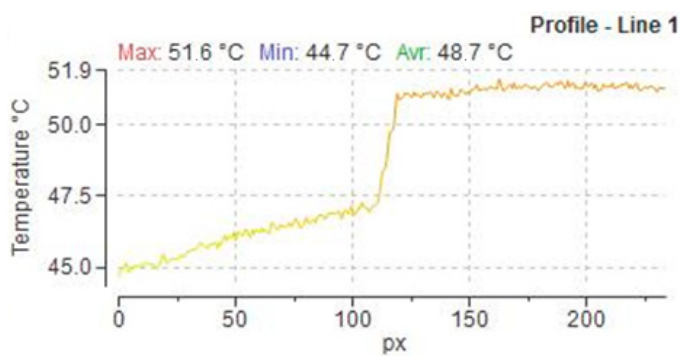

(b)

Figure 15. Vertical temperature profile for selected valves (profile line 1 (a) and 2 (b)).

Histograms (Figure 16) shows that over $5 \%$ of valves surface reached a temperature $51-52{ }^{\circ} \mathrm{C}$ and $55-57^{\circ} \mathrm{C}$ for first and second profile respectively.

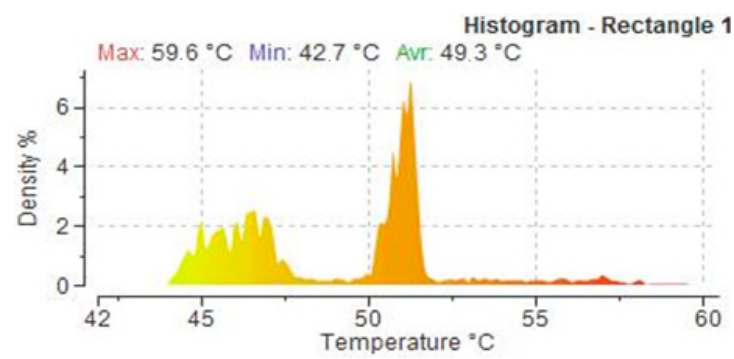

(a)

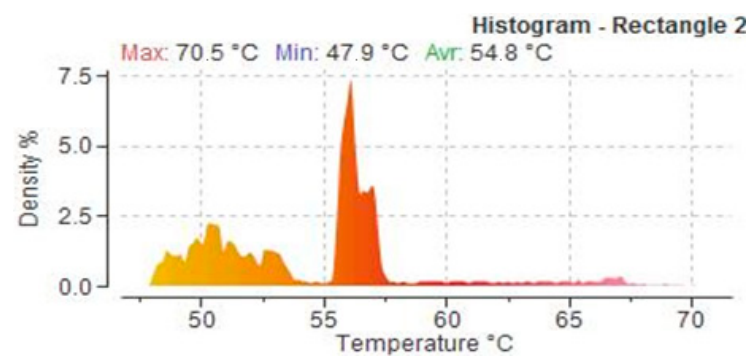

(b)

Figure 16. Temperature histograms for valves surface 1 (a) and 2 (b). 
The temperature of the operating electric motor and a drive shaft which connects the electric motor with the hydraulic pump was investigated. The maximum temperatures of the operating motor do not exceed 42.5 and $43.6^{\circ} \mathrm{C}$, respectively.

Temperature analysis of the selected elements of hydraulic pump block was performed during long term (few weeks) operation of HRS. The highest temperature occurs on hydraulic pump elements (valves). Results show that temperature does not create a hazard and does not effect the general safety level.

\subsubsection{HRS Failures}

During operational and safety tests some elements of prototype failed. As a result of the test, HRS construction was improved: (i) the valves and electromagnetic valve supplier were changed; (ii) installation place of feeding gas pressure sensor was changed. This elements failure was caused by the Joule-Thompson effect.

\section{Conclusions}

The aim of the investigation was to perform operational and safety tests for a final production prototype of CNG home fast refueling system (CNG HRS). During operational tests, natural gas demand $\mathrm{m}^{3} / \mathrm{h}$ and energy consumption $\mathrm{kW} / \mathrm{h}$ were investigated. Based on test results, the following costs were determined: (i) for one full refueling; (ii) for one hour of HRS operation in different conditions; and (iii) for net cost of $1 \mathrm{Nm}^{3} \mathrm{CNG}$ [27].

The average HRS full cycle duration (including buffering and refueling) was $7 \mathrm{~h}$ and $32 \mathrm{~min}$. The average electrical energy consumption was $5.52 \mathrm{kWh}$. The average natural gas consumption was $7.5 \mathrm{~m}^{3}$. The total cost of a full buffering and refueling cycle in Polish conditions was estimated at the level of 4.932 EUR where 0.437 EUR was the electricity cost and 3.495 EUR was the natural gas cost $[28,29]$.

The analysis of the obtained results indicates that the hourly electric energy consumption for Scenario 1 and ambient conditions equals $0.74 \mathrm{~kW} / \mathrm{h}$. The natural gas consumption was approximately $1.00 \mathrm{~m}^{3} / \mathrm{h}$. The cost of one hour of HRS operation in Polish conditions was estimated at the level of 0.525 EUR where 0.059 EUR was the electricity cost and 0.466 EUR was the natural gas cost. In the 4-h cycle, the electric energy consumption and natural gas consumption were $3.2-3.3 \mathrm{kWh}$ and $4.5-4.6 \mathrm{~m}^{3}$ respectively. In the 5-h cycle, the electric energy consumption and natural gas consumption was 4.0-4.1 $\mathrm{kWh}$ and 5.6-5.7 $\mathrm{m}^{3}$ respectively. For the 6-h cycle, the electric energy consumption and natural gas consumption were $4.8-5.0 \mathrm{kWh}$, and $6.6-6.8 \mathrm{~m}^{3}$ respectively.

The results presented above indicate that the hourly energy and natural gas consumption for Scenario 2 and ambient conditions equal $0.8-0.83 \mathrm{~kW} / \mathrm{h}$ and $1.1-1.15 \mathrm{~m}^{3} / \mathrm{h}$, respectively. The cost of one hour of HRS operation for interrupted buffering cycles was estimated at 0.576-0.602 EUR, where $0.513-0.536$ EUR is the natural gas cost and $0.063-0.066$ EUR is the cost of electricity.

Additionally, the cost of $1 \mathrm{Nm}^{3}$ of CNG was estimated.

To compare HRS with large scale CNG refueling infrastructure, the costs of $1 \mathrm{Nm}^{3} \mathrm{CNG}$ was estimated for both solutions. For NGV fueling with HRS, in the case of using HRS, CNG refueling cost is $0.525 \mathrm{EUR} / \mathrm{Nm}^{3}$ (where $0.059 \mathrm{EUR}$ is the electricity cost and $0.466 \mathrm{EUR}$ is the natural gas cost). In cases where large scale CNG refueling infrastructure is used, the cost is $0.766 \mathrm{EUR} / \mathrm{Nm}^{3}$ [30]. This result shows that home refueling appliances might become a solution for filling the gap in CNG refueling infrastructure.

Safety test results for leakage, fill pressure change, interrupted power and gas supply, temperature, and unexpected failures demonstrated valid operation of HRS which positively affects the general safety level. 
Author Contributions: Conceptualization, S.K., M.Ł., A.S., K.L., and A.O.; Formal analysis, S.K. and A.O.; Funding acquisition, M.Ł. and A.S.; Investigation, S.K., A.S., and A.O.; Methodology, A.O., K.L., and M.Ł.; Supervision, K.L., M.Ł., and A.S.; Validation, S.K. and A.O.; Visualization, S.K. and A.O.; Writing一original draft, A.O. and S.K.; Writing-review and editing, S.K. and A.O.

Funding: This research was funded by EIT InnoEnergy, CC Poland Plus project "Compressed Natural Gas Home Refueling Station", GA no. 7.7.190.70130.

Conflicts of Interest: The authors declare no conflict of interest.

\section{Nomenclature}

$\begin{array}{ll}\text { CNG } & \text { compressed natural gas } \\ \text { CNG-HRS } & \begin{array}{l}\text { compressed natural gas home fast refueling station } \\ \text { electronic control unit } \\ \text { ECU }\end{array} \\ \text { ESD } & \text { emergency shutdown system } \\ \text { GHG } & \text { Joule-Thomson } \\ \text { J-T } & \text { liquefied natural gas } \\ \text { LNG } & \text { natural gas } \\ \text { NG } & \text { natural gas vehicle } \\ \text { NGV } & \text { renewable natural gas (i.e., biomethane) } \\ \text { RNG } & \end{array}$

\section{References}

1. Kułaga, P.; Rudkowski, M. Blue Corridor Project. Wiele korzyści dla Europy. Nafta E Gaz Biznes. 2004. Available online: https://www.cire.pl/pliki/2/blue_corridor647035487.pdf (accessed on 30 October 2019).

2. Chu, S.; Majumdar, A. Opportunities and challenges for a sustainable energy future. Nature 2012, 488, 294. [CrossRef] [PubMed]

3. Khan, M.I.; Yasmin, T.; Shakoor, A. Technical overview of compressed natural gas (CNG) as a transportation fuel. Renew. Sustain. Energy Rev. 2015, 51, 785-797. [CrossRef]

4. Ogden, J.; Jaffe, A.M.; Scheitrum, D.; McDonald, Z.; Miller, M. Natural gas as a bridge to hydrogen transportation fuel: Insights from the literature. Energy Policy 2018, 115, 317-329. [CrossRef]

5. Le Fevre, C. The Prospects for Gas in the European Transportation Sector. In The European Gas Markets; Springer: Berlin/Heidelberg, Germany, 2017; pp. 125-145.

6. NGV Global. Available online: www.ngvglobal.org (accessed on 30 October 2019).

7. Le Fevre, C.N. A Review of Prospects for Natural Gas as a Fuel in Road Transport; Oxford Institute for Energy Studies: Oxford, UK, 2019.

8. Engerer, H.; Horn, M. Natural gas vehicles: An option for Europe. Energy Policy 2010, 38, 1017-1029. [CrossRef]

9. The Natural \& bio Gas Vehicle Association (NGVA Europe). Available online: www.ngva.eu/stations-map/ (accessed on 30 October 2019).

10. European Commission. White Paper on Transport. In Roadmap to a Single European Transport Area: Towards a Competitive and Resource Efficient Transport System; Publications Office of the European Union: Brussels, Belgium, 2011.

11. LNG Blue Corridors. Available online: www.lngbc.eu (accessed on 30 October 2019).

12. European Parliament. Directive 2014/94/EU of the European Parliament and of the Council of 22 October 2014 on the deployment of alternative fuels infrastructure. Chall. Knowl. Soc. 2014, L 307, 855-861.

13. Snam, I.G.U.; BCG. Global Gas Report 2018; Snam and the International Gas Union (IGU) and the Boston Consulting Group: Washington, DC, USA, 2018.

14. Ahmad, H. Demand Assessment and Design Aspect of City Gas Distribution Network. In Natural Gas Markets in India; Springer: Singapore, 2017; pp. 217-248. [CrossRef]

15. Kelley, S.; Kuby, M. Decentralized refueling of compressed natural gas (CNG) fleet vehicles in Southern California. Energy Policy 2017, 109, 350-359. [CrossRef]

16. U.S. Energy Information Administration (US EIA); U.S. Department of Energy. Annual Energy Outlook 2015-With Projections to 2040; U.S. Energy Information Administration: Washington, DC, USA, 2015. 
17. Abbanat, B.A. Alternative Fuel Vehicles: The Case of Compressed Natural Gas (CNG) Vehicles in California Households. Master's Thesis, University of California, Oakland, CA, USA, October 2001.

18. Li, X.; Ogden, J.M.; Kurani, K.S. An overview of automotive home and neighborhood refueling. World Electr. Veh. J. 2009, 3, 432-439. [CrossRef]

19. Hygen. Home Refueling Appliance for Gaseous Fuel Powered Vehicles. Available online: hygengroup.com (accessed on 30 June 2019).

20. Urząd Regulacji Energetyki. Sprawozdanie z działalności Prezesa Urzędu Regulacji Energetyki w 2018 r; Urząd Regulacji Energetyki-Energy Regulatory Office: Warszawa, Poland, 2019; p. 51. (In Polish)

21. Kuczyński, S.; Liszka, K.; Łaciak, M.; Oliinyk, A.; Strods, R.; Szurlej, A. Technological and safety aspects of CNG home fast refueling units. AGH Drill. Oil Gas 2016, 33, 425-432. [CrossRef]

22. Shipley, E.P. Study of Natural Gas Vehicles (NGV) during the Fast Fill Process. Master's Thesis, West Virginia University, Morgantown, WV, USA, 2002.

23. Farzaneh-Gord, M.; Saadat-Targhi, M.; Khadem, J. Selecting optimal volume ratio of reservoir tanks in CNG refueling station with multi-line storage system. Int. J. Hydrog. Energy 2016, 41, 23109-23119. [CrossRef]

24. CSA Group. Residential Fueling Appliances; ANSI/CSA NGV 5.1-2015; CSA Group: Toronto, ON, Canada, 2015; ISBN 978-1-77139-736-0.

25. Waterland, L.R.; Powars, C.; Stickles, P. Safety Evaluation of the Fuelmaker Home Refueling Concept; No. NREL/SR-540-367800; National Renewable Energy Lab.: Golden, CO, USA, 2005.

26. Farzaneh-Gord, M.; Rahbari, H.R.; Deymi-Dashtebayaz, M. Effects of natural gas compositions on CNG fast filling process for buffer storage system. Oil Gas Sci. Technol. Rev. D'ifp Energy Nouv. 2014, 69, 319-330. [CrossRef]

27. Kagiri, C.; Zhang, L.; Xia, X. Optimization of a compressed natural gas station operation to minimize energy cost. Energy Procedia 2017, 142, 2003-2008. [CrossRef]

28. Tauron. Available online: www.tauron.pl/-/media/offer-documents/dokumenty-do-taryfy/gze/gze_ki_ taryfa_sprzedazowa_energii_elektrycznej.ash (accessed on 30 October 2019).

29. Polskie Górnictwo Naftowe i Gazownictwo SA (PGNiG). Available online: http://pgnig.pl/dla-domu/taryfa (accessed on 30 October 2019).

30. Polskie Górnictwo Naftowe i Gazownictwo SA (PGNiG). Available online: http://pgnig.pl/cng/cennik-cng (accessed on 30 October 2019). 